\title{
STOCK MARKET EFFICIENCY IN AFRICA: EVIDENCE FROM RANDOM WALK HYPOTHESIS
}

\author{
Rui Dias ${ }^{1}$ \\ Hortense Santos ${ }^{2}$
}

DOI: https://doi.org/10.31410/LIMEN.2020.25

\begin{abstract}
This paper aims to test the efficient market hypothesis, in its weak form, in the stock markets of BOTSWANA, EGYPT, KENYA, MOROCCO, NIGERIA and SOUTH AFRICA, in the period from September 2, 2019 to September 2, 2020. In order to achieve this analysis, we intend to find out if: the global pandemic (Covid-19) has decreased the efficiency, in its weak form, of African stock markets? The results therefore support the evidence that the random walk hypothesis is not supported by the financial markets analyzed in this period of global pandemic. The values of variance ratios are lower than the unit, which implies that the yields are autocorrelated in time and, there is reversal to the mean, and no differences were identified between the stock markets analyzed. The authors consider that the results achieved are of interest to investors looking for opportunities for portfolio diversification in these regional stock markets.
\end{abstract}

Keywords: Random walk, Africa stock markets, Portfolio diversification.

\section{INTRODUCTION}

I

$\mathrm{n}$ recent decades, the phenomenon of globalization has accentuated the synchronizations between international financial markets demonstrating that the correlation between international financial markets has increased. If a given stock market is strongly linked to another country's stock market, the financial stability of the former depends in part on the financial stability of the second. For this reason, a close or strong link between markets increases the levels of vulnerability to external shocks and, consequently, influences the economic conditions and welfare levels of their respective countries, as well as the efficiency of the market itself (Alexandre, Heliodoro and Dias, 2019; Dias, da Silva and Dionysus, 2019; Dias, Heliodoro and Alexandre, 2019, 2020; Alexandre, Dias and Heliodoro, 2020; Heliodoro et al. , 2020, 2020; Heliodoro, Dias and Alexandre, 2020; Dias, Alexandre and Heliodoro, 2020, 2020; Dias, Heliodoro, et al. , 2020, 2020a, 2020b; Dias, Sparrow, et al. , 2020) .

Stock markets in Africa are increasing interest among international investors, attracting significant private investment. There are currently more than twenty-nine (29) stock exchanges in Africa with significant disparities in market size, number of listed companies, volume of transactions, access to information. These institutional limitations together with the existence of information asymmetry, agency problems, regulatory limitations and the presence of financial institutions have implications for the efficient market hypothesis (HME) in these regional stock exchanges. (Hawaldar, Rohith, and Pinto, 2020; Lawal, Nwanji, Adama, and

\footnotetext{
1 School of Business and Administration, Polytechnic Institute of Setúbal, Portugal and CEFAGE-UE, IIFA, University of Évora, Portugal

2 School of Business and Administration, Polytechnic Institute of Setúbal, Portugal
} 
Otekunrin, 2017; Lawal, Somoye, and Babajide, 2017; Tweneboah, Owusu, and Oseifuah, 2019).

Thus, the study aimed to test the efficient market hypothesis, in its weak form, in the stock markets of BOTSWANA, EGYPT, KENYA, MOROCCO, NIGERIA and SOUTH AFRICA, in the period from September 2, 2019 to September 2, 2020. In order to achieve this analysis, it is intended to find out if: the global pandemic (Covid-19) has decreased the efficiency, in its weak form, of the African financial markets? The results suggest that the random walk hypothesis is not supported by the financial markets analyzed in this period of global pandemic. These findings show that prices do not fully reflect the information available and that price changes are not i.i.d., in all markets. The high sensitivity of prices to the arrival of new information will be due to the climate of pessimism and uncertainty experienced by investors during this period of global pandemic.

In terms of contributions to the existing literature, this investigation is justified due to the gaps in the literature on the efficient market hypothesis (HME) in the stock exchanges of the African continent, being the same inconclusive with hybrid evidence. In view of these facts, this study is justified by the need to mitigate the empirical divergences in Africa's stock markets. In addition, as these stock exchanges develop in the presence of imperfect information, investors, regulators and other participants call for transparency on the efficiency or inefficiency of these stock markets to avoid sharp structural breakdowns, which could cause significant losses for domestic and international investors operating in these regional stock markets.

In terms of structure, this paper is organized into 5 sections. In addition to the current introduction, the section 2 presents a Literature Review with regard to articles on the random walk hypothesis in the African financial markets, in section 3 the methodology is described, and section 4 contains the data and results. Section 5 presents the general conclusions of the work.

\section{LITERATURE REVIEW}

A market is designated as efficient, when all relevant information about the stock price are reflected in the market price. The lack of consensus among economists and financial analysts regarding market efficiency requires the study of the efficient market hypothesis (HME). Another significant reason to study market efficiency is the role of stock markets acting as financial intermediaries between the saver and the borrower in the distribution of scarce resources via the price mechanism (Jain, 2020; Karasiński, 2020).

Smith, Jefferis, and Ryoo (2002), Simons and Laryea (2006), Obayagbona and Igbinosa (2015), Kelikume (2016), Abakah, Alagidede, Mensah, and Ohene-Asare (2018), Hawaldar, Rohith, and Pinto (2020) examined the random walk hypothesis in African markets by testing whether arbitrage levels are accentuated to the point where investors obtain anomic profitability without incurring additional risk. Smith, Jefferis, and Ryoo (2002) show that stock markets in Egypt, Kenya, Morocco, Nigeria, Zimbabwe, Botswana and Mauritius show signs of (in) efficiency in its weak form. Simons and Laryea (2006) show that South Africa's stock market is efficient, in its weak form, while the stock markets of Ghana, Mauritius and Egypt do not have random walk properties. Obayagbona and Igbinosa 2015) show dependence on profitability series and, therefore, non-randomness, validating that the Nigerian market shows signs of(in) efficiency, in its weak form. Kelikume (2016) shows that the Nigerian stock market follows a random walk behavior, that is, stock prices fully reflect all the information 
available in the market and investors are unable to obtain anomic profitability with the same level of risk. Abakah, Alagidede, Mensah, and Ohene-Asare (2018) show that the stock markets of South Africa, Nigeria, Egypt, Ghana and Mauritius follow the random walk hypothesis, while the markets of Ghana and Mauritius show evidence of some (in)efficiency, in its weak form. Hawaldar, Rohith, and Pinto (2020) examined the predictability of 8 African stock markets; the authors show that investors fail to obtain incredible profitability, based on historical prices, that is, these markets are efficient, in their weak form.

In summary, this work aims to contribute to the provision of information to investors and regulators in African financial markets, where individual and institutional investors seek to efficiently diversify their portfolios, in a period of uncertainty and lack of confidence arising from the global pandemic (Covid-19).

\section{METHODOLOGY}

\section{Data}

The stock markets analyzed are from BOTSWANA, EGYPT, KENYA, MOROCCO, NIGERIA and SOUTH AFRICA, from September 2, 2019 to September 2, 2020. The prices index of the markets of BOTSWANA, KENYA and NIGERIA are in Euro currency, the rest are in local currency. The time scales are daily and were obtained from the DataStream.

\section{Methodology}

Research will develop throughout several stages. Market graphs were made, at levels, and in profitability, to estimate the evolution of the markets under study. The characterization of the sample will be performed using descriptive statistics in order to verify whether the data follow a normal distribution. To evaluate whether the time series follow a white noise (mean $=0$; constant variance), the tests of unit roots in Levin, Lin , and Chu panel (2002), Breitung (2000) will be used, which postulate the same null hypotheses. To measure the structural breaks, graphs of stability to the residues will be performed, as well as the test by Clemente et al. (1998) that will determine the date of the structure break. To answer the question of investigation we will use the reason method of the variance proposed by Lo and Mackinlay (1988) in order to evaluate the autocorrelation between the series of profitability. This is being classified as a parametric test. The efficient market hypothesis in its weak form establishes that it is not possible to predict future prices based on historical prices. The author Rosenthal (1983) advocates whether a market is efficient in its weak form, then there should be no linear dependence between the profitability allocated both in the statistical sense (absence of autocorrelation) and in the economic sense (no positive profitability after considering transaction costs). The Lo and Mackinlay model (1988) defines how the $P_{t}$ price of an asset in $\mathrm{t}$ and $X_{t}$ as the natural logarithm of $X_{t}$, the random walk hypothesis is given by:

$$
X_{t}=\mu+X_{t-1}+\epsilon_{t}
$$

Where $\mu$ is an arbitrary motion parameter and $\epsilon_{t}$ is the random error term. The authors show that an important characteristic of the random walk process is that the variance of increments increases linearly according to the observation interval. That is, the variance of $X_{t}-X_{t-2}$ is twice the variance of $X_{t}-X_{t-1}$. Thus, the validity of a random walk model can be tested by comparing profitability variance estimators at different frequencies. For example, the variance of the series of weekly yields should be five times greater than the variance of the daily yields. The model consists of testing whether the ratio of variance to different intervals weighted by their duration is equal to one. 


\section{RESULTS}

Figure 1 shows the evolution of financial markets, at levels, in the period from September 2, 2019 to September 2, 2020, which is a period of high complexity, as it crosses the global pandemic outbreak (Covid-19). Most markets show structural breakdowns in February and March 2020.

Figure 1. Evolution, in levels, of the 6 stock markets, in the period from September 2, 2019 to September 2, 2020.
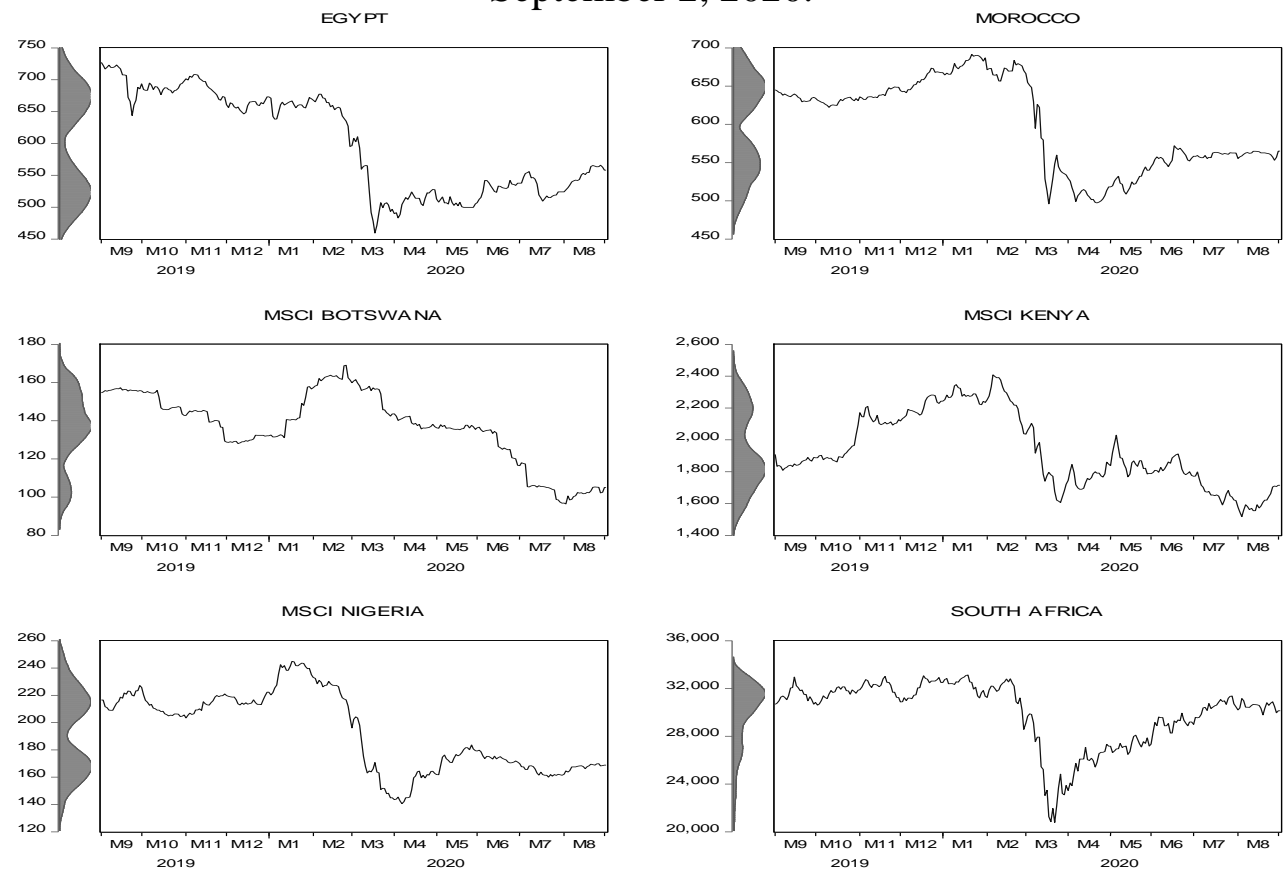

Source: Own elaboration

Figure 2 shows the evolution in profitability of the 6 financial markets under review. The graphical representation allows you to visualize very similar behavior patterns during the sampling period. However, there is a period that stands out, as patterns have been manifestly affected by the global pandemic (Covid-19), corresponding to February and March 2020, corroborated by a sharp drop in financial markets.

Figure 2. Evolution, return, of the 6 stock markets, in the period from September 2, 2019 to

September 2, 2020

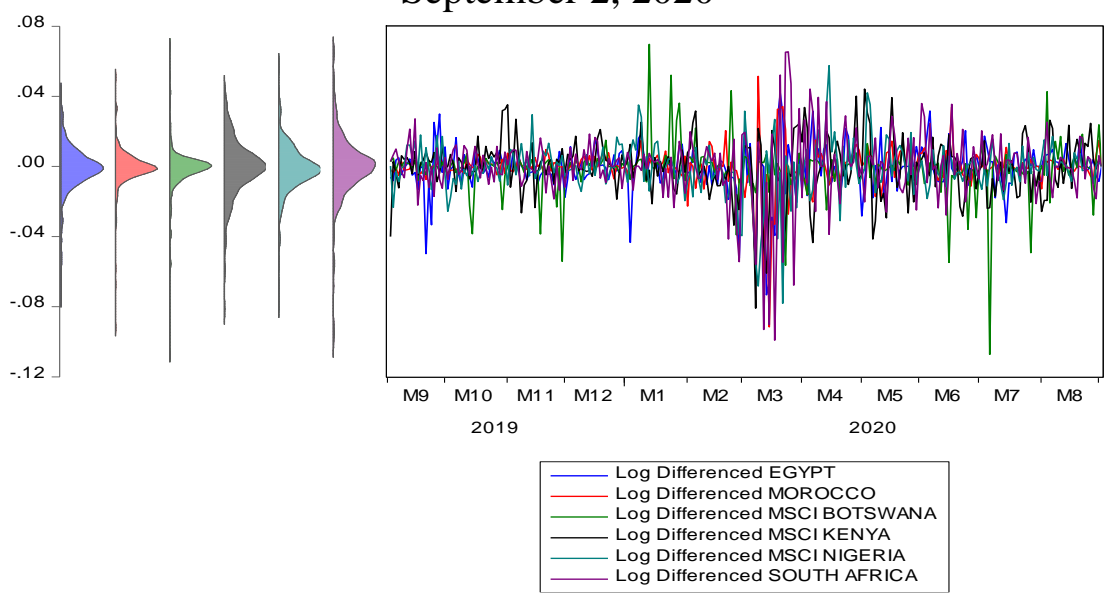

Source: Own elaboration 
Figure 3 shows the averages of the 6 financial markets in an area, all of which have negative average yields, South Africa (-6.77E-05), Kenya (-0.000407), Morocco (-0.000504), Nigeria (0.000946), Egypt (-0-001006) and Botswana (-0.001470).

Figure 3. Evolution of the average yields of the 6 stock markets in the period from September 2, 2019 to $\underset{\text { Means }}{\text { September 2, } 2020 .}$

DLOG(EGYPT)

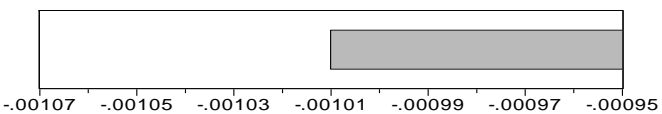

DLOG(MSCI BOTSWANA)

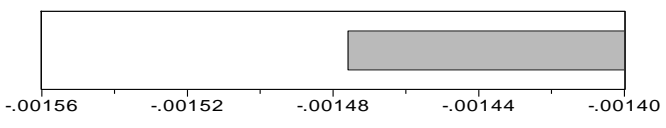

DLOG(MSCI NIGERIA)

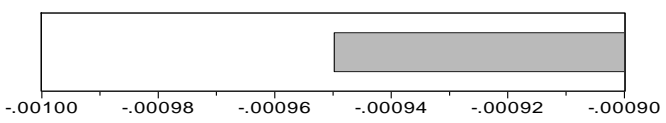

DLOG(MOROCCO)

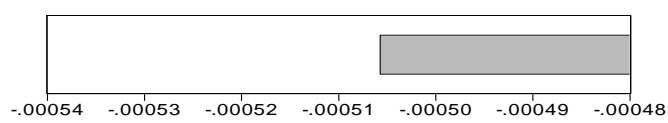

DLOG(MSCI KENYA)

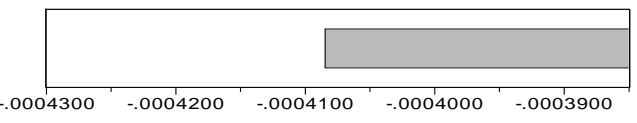

DLOG(SOUTH AFRICA)

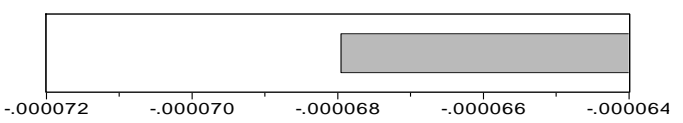

Source: Own elaboration

Figure 4 shows the standard deviations of the 6 stock markets in an area. As with averages, standard deviations also have very similar values in the financial markets under analysis: the market with the lowest standard deviation is Morocco (0.012), Egypt and Botswana (0.014), Nigeria (0.015), Kenya (0.016) and South Africa (0.019), concluding that Morocco is the financial market that shows the lowest risk when compared to the remaining markets.

Figure 4. Evolution of standard deviations from the 6 stock markets in the period from September 2, 2019 to September 2, 2020.

Standard Deviations

DLOG(EGYPT)

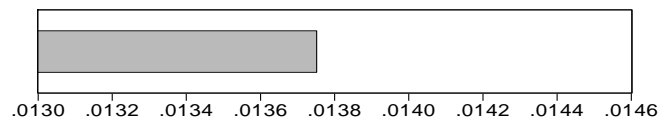

DLOG(MSCI BOTSWANA)

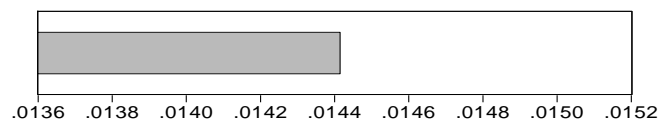

DLOG(MSCI NIGERIA)

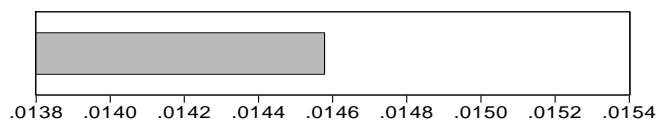

DLOG(MOROCCO)

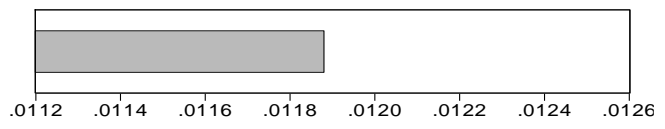

DLOG(MSCI KENYA)

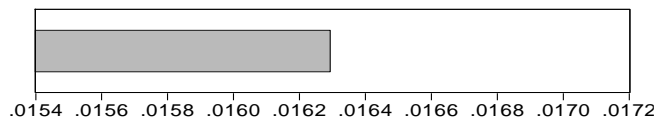

DLOG(SOUTH AFRICA)

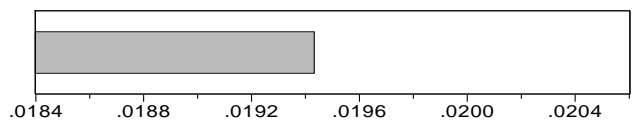

Source: Own elaboration

Figure 5 shows the Skewness of the 6 financial markets under analysis and we can verify all the markets under analysis have negative asymmetries, The Morocco market (-2.349464) presents the most pronounced asymmetry, followed by Botswana (-1.572172), Egypt (-1.493110), South Africa (-1.184155), Nigeria (-0.867744) and Kenya (-0.760551). These findings indicate that the data do not follow a normal distribution (Skewness $=0)$. 
Figure 5. Evolution of the Skewness of the 6 stock markets September 2, 2019 to September 2,2020

Skewness

DLOG(EGYPT)

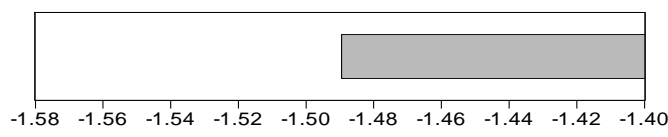

DLOG(MSCI BOTSWANA)

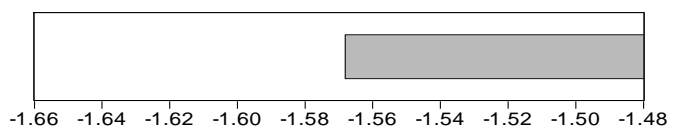

DLOG(MSCI NIGERIA)

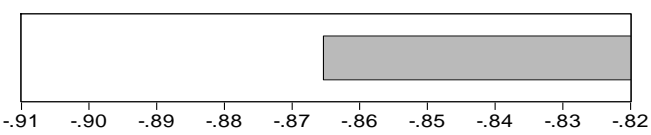

DLOG(MOROCCO)

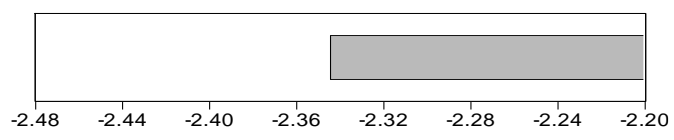

DLOG(MSCI KENYA)

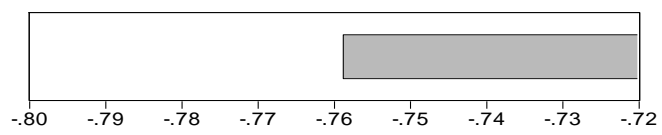

DLOG(SOUTH AFRICA)

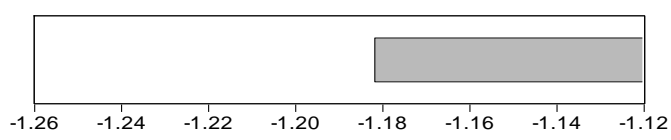

Source: Own elaboration

Figure 6 shows the Kurtosis of the 6 financial markets under analysis and we can see that the Morocco market has the sharpest kurtosis (22.43120), followed by Botswana (18.81400), South Africa (9.911942), Egypt (9.589017), Nigeria (8.963956) and Kenya (6.067979). These results confirm the assumptions that time series do not follow a normal distribution, because asymmetry is different from reference values (Skewness $=0$; Kurtosis $=3$ ).

Figure 6. Kurtosis evolution of the 6 stock markets in the period from September 2, 2019 to September 2, 2020. Kurtoses

DLOG(EGYPT)

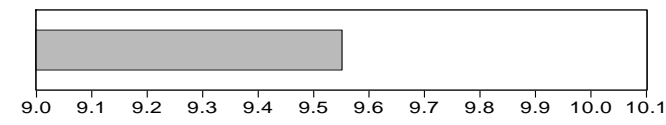

DLOG(MSCI BOTSWANA)

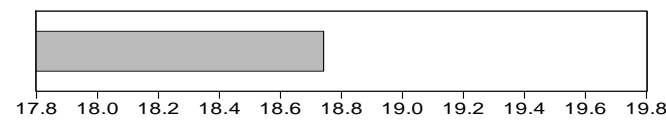

DLOG(MSCI NIGERIA)

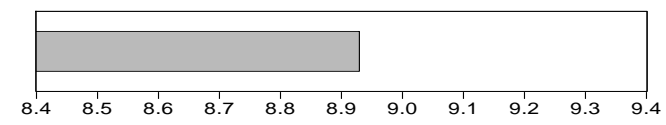

DLOG(MOROCCO)

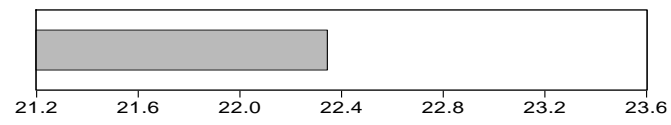

DLOG(MSCI KENYA)

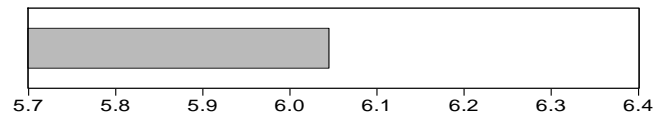

DLOG(SOUTH AFRICA)

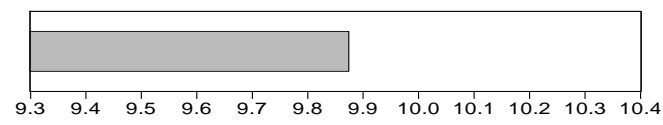

Source: Own elaboration

Since we are in the presence of time successions, we should study the stationary nature of the series relating to the 6 financial markets under analysis. To do so, we use the tests of unitary roots in Levin panel, Lin, and Chu (2002), Breitung (2000) that postulate the same null hypotheses. The intersections of the unit root tests in panel show the temporality of the time series (return), that is, we are facing a white noise (mean $=0$; constant variance) (see tables 1 and 2). 
Table 1. Levin, Lin, and Chu parking test (2002), applied to the 6 stock markets, in the period from September 2, 2019 to September 2, 2020.

\begin{tabular}{|c|c|c|c|c|c|c|c|}
\hline Method & & & & Statistic & & Prob.** & \\
\hline Levin, Lin \& Chu $t^{*}$ & & & & -39.2723 & & 0.0000 & \\
\hline Series & $\begin{array}{l}\text { 2nd stage } \\
\text { Coefficient }\end{array}$ & $\begin{array}{l}\text { Variance } \\
\text { Of Reg }\end{array}$ & $\begin{array}{c}\text { HAC of } \\
\text { Dep. }\end{array}$ & Lag & $\begin{array}{l}\text { Max } \\
\text { Lag }\end{array}$ & $\begin{array}{l}\text { Band- } \\
\text { Width }\end{array}$ & Note \\
\hline $\mathrm{D}(\mathrm{EGYPT})$ & -0.74461 & 57.897 & 0.8347 & 0 & 15 & 149.0 & 261 \\
\hline D(MOROCCO) & -0.83756 & 45.573 & 2.0336 & 0 & 15 & 48.0 & 261 \\
\hline D(MSCI BOTSWANA) & -0.95198 & 3.6135 & 0.1632 & 0 & 15 & 45.0 & 261 \\
\hline D( MSCI KENYA) & -0.80425 & 824.10 & 52.884 & 1 & 15 & 69.0 & 260 \\
\hline MSCI NIGERIA & -0.69499 & 6.6073 & 0.4447 & 0 & 15 & 34.0 & 261 \\
\hline \multirow[t]{2}{*}{ D(SOUTH AFRICA) } & -1.03102 & 263623 & 4262.7 & 0 & 15 & 131.0 & 261 \\
\hline & Coefficient & T-Stat & Reg SE & $\mathrm{mu}^{*}$ & sig* & & Note \\
\hline Pooled & -0.84198 & -32.990 & 1.007 & -0.508 & 0.740 & & 1565 \\
\hline
\end{tabular}

Note: ** Probabilities for Fisher tests are computed using an asymptotic Chi-square distribution. All other test assumes asymptotic normality.

Source: Own elaboration

Table 2. Breitung stationary test (2000) applied to the 6 stock markets, in the period from September 2, 2019 to September 2, 2020.

\begin{tabular}{|c|c|c|c|c|}
\hline Method & & & Statistic & Prob.** \\
\hline Breitung t-stat & & & -27.6141 & 0.0000 \\
\hline Series & $\begin{array}{c}\text { S.E. of } \\
\text { Regression }\end{array}$ & Lag & Max Lag & Note \\
\hline $\mathrm{D}$ (EGYPT) & 9.62418 & 0 & 15 & 261 \\
\hline D(MOROCCO) & 8.87201 & 0 & 15 & 261 \\
\hline D(MSCI BOTSWANA) & 2.63127 & 0 & 15 & 261 \\
\hline D( MSCI KENYA) & 35.1423 & 1 & 15 & 260 \\
\hline MSCI NIGERIA & 3.18825 & 0 & 15 & 261 \\
\hline \multirow[t]{2}{*}{ D(SOUTH AFRICA) } & 739.088 & 0 & 15 & 261 \\
\hline & Coefficient & T-Stat & Reg SE & Note \\
\hline Pooled & -0.68642 & -27.614 & 0.025 & 1559 \\
\hline
\end{tabular}

Note: ** Probabilities for Fisher tests are computed using an asymptotic Chi-square distribution. All other tests assume asymptotic normality.

Source: Own elaboration

Figure 7 shows the stability tests performed on stock market residues, measuring the existence of disturbances in variance. Additionally, when examining the graphs and the probability limits of $95 \%$ we verified the existence of violation of probability limits, therefore, the time series show an unstable behavior.

Figure 7. Stability tests carried out on the residues of the 6 stock markets from September 2, 2019 to September 2, 2020.
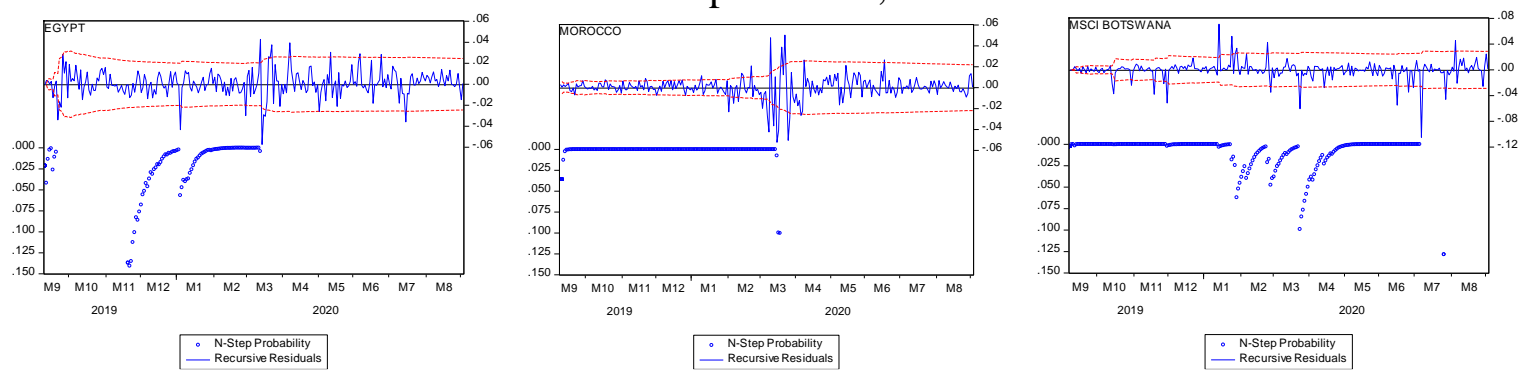

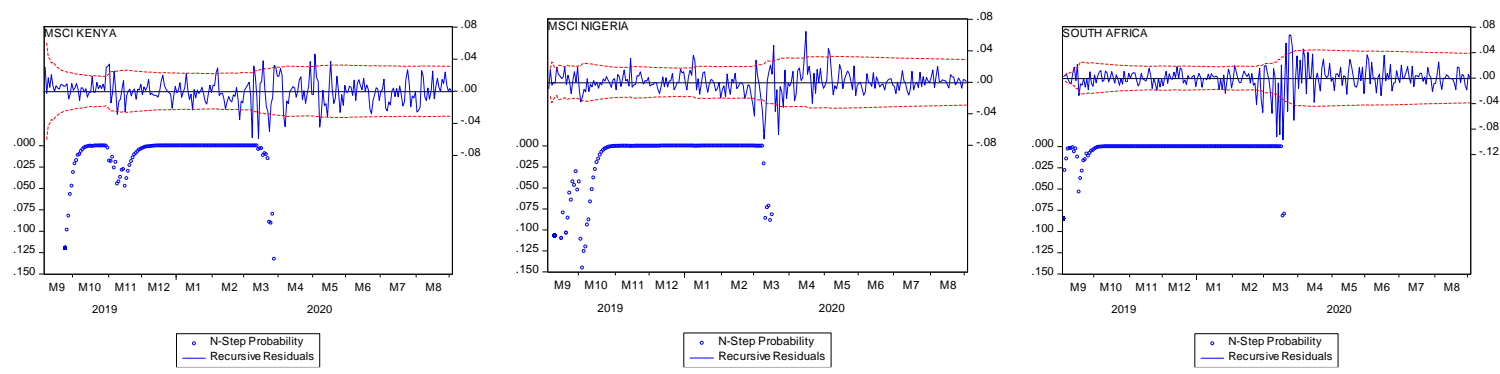

Source: Own elaboration

Figure 8 shows the results of unitary root tests, with structural breaks, by Clemente et al. (1998) , highlighting the existence of structural breakdowns, mostly in March 2020, with the exception of BOTSWANA and MOROCCO's stock markets, which was expected due to the evolution of the global pandemic (Covid-19). These findings are corroborated by the authors Sansa (2020), He, Liu, Wang, and Yu (2020), who show structural breakdowns in financial markets resulting from the global pandemic (Covid-19).

Figure 8. Parking tests with structural breaks by Clemente et al. (1998), return, referring to the 6 stock markets, from September 2, 2019 to September 2, 2020.
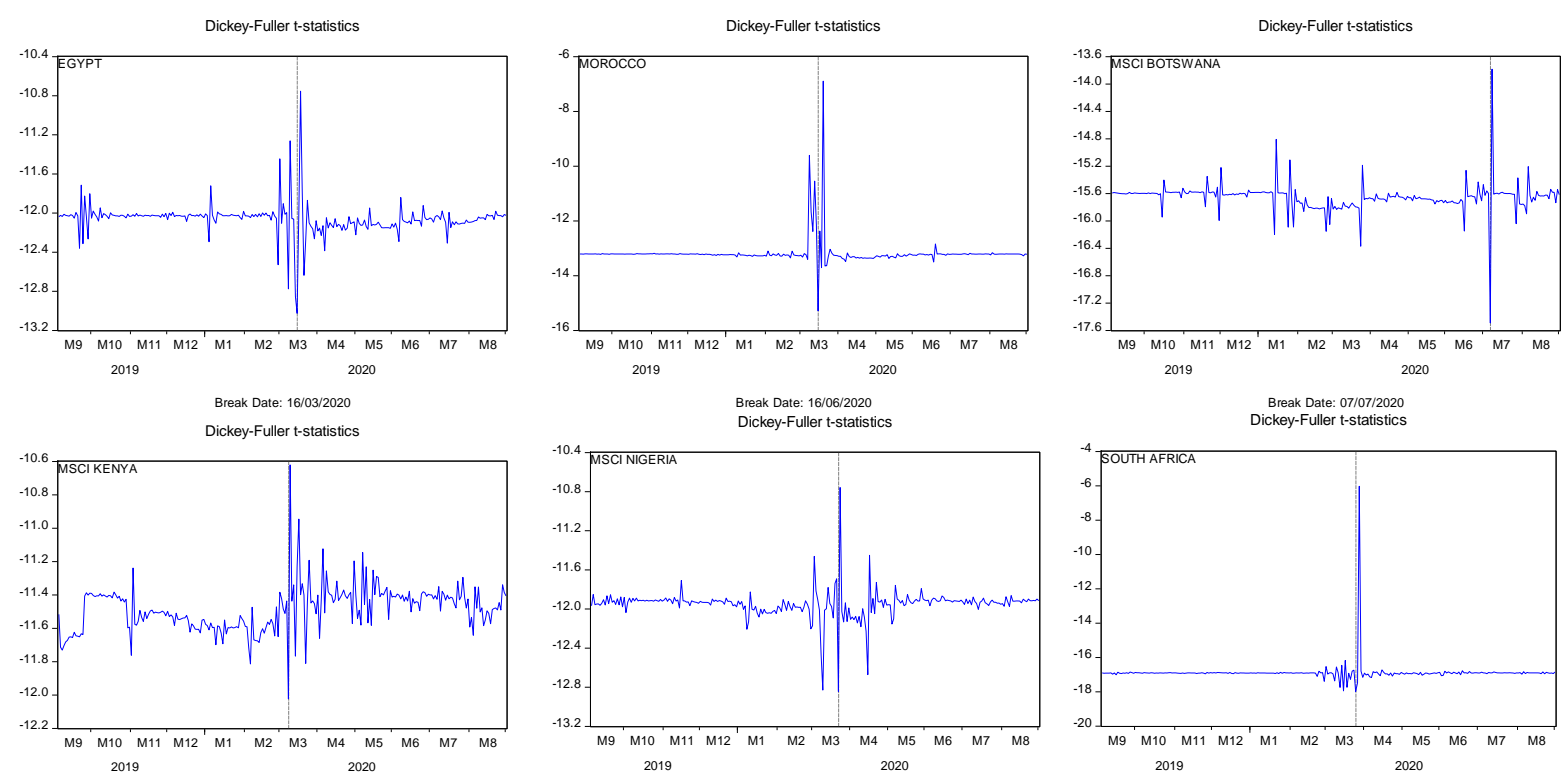

Source: Own elaboration

Table 3 presents the results of the variance ratio methodology proposed by Lo and Mackinlay (1988) in order to evaluate the autocorrelation between the profitability series. In all cases, statistics were calculated for 2- 16-day lags, with intervals of 1 day. Given the results obtained from the variance test, the random walk hypothesis is rejected in all stock indexes. The results support the conclusion that the random walk hypothesis is not followed by the financial markets analyzed in this period of global pandemic. It is verified that profitability is autocorrelated in time, with reversal to the mean, because the values of variance ratios are lower than the unit. Given these assumptions, markets tend to react abruptly to information due to the uncertainty and pessimism experienced in the global economy arising from the global pandemic of 2020. In addition, the hypothesis of informational efficiency of financial markets may be called into question; these results are corroborated by the studies of the authors Aggarwal (2018), Sadat and Hasan (2019). 
Table 3. Lo and Mackinlay Variance Ratio scans, return, referring to the 6 stock markets, from September 2, 2019 to September 2, 2020.

Null Hypothesis: EGYPT is a random walk

\begin{tabular}{ccccc}
\hline \hline \multicolumn{2}{c}{ Joint Tests } & Value & Df & Probability \\
\hline \hline \multicolumn{2}{c}{ Max |z| (at period 2) } & 5.908907 & 262 & 0.0000 \\
Wald (Chi-Square) & 58.26419 & 15 & 0.0000 \\
\hline \multicolumn{2}{c}{ Individual Tests } & & & Probability \\
\hline Period & Var. Ratio & Std. Error & z-Statistic & 0.0000 \\
3 & 0.634947 & 0.061780 & -5.908907 & 0.0000 \\
4 & 0.463401 & 0.092096 & -5.826492 & 0.0000 \\
5 & 0.318996 & 0.115580 & -5.892052 & 0.0000 \\
6 & 0.292183 & 0.135354 & -5.229391 & 0.0000 \\
7 & 0.273366 & 0.152725 & -4.757804 & 0.0000 \\
8 & 0.242114 & 0.168384 & -4.500925 & 0.0000 \\
9 & 0.208281 & 0.182748 & -4.332289 & 0.0000 \\
10 & 0.194891 & 0.196088 & -4.105846 & 0.0000 \\
11 & 0.171515 & 0.208594 & -3.971757 & 0.0000 \\
12 & 0.163539 & 0.220403 & -3.795149 & 0.0000 \\
13 & 0.156782 & 0.231619 & -3.640545 & 0.0000 \\
14 & 0.142511 & 0.242322 & -3.538636 & 0.0000 \\
15 & 0.146516 & 0.252577 & -3.379107 & 0.0010 \\
16 & 0.136941 & 0.262435 & -3.288663 & 0.0010 \\
\hline \hline
\end{tabular}

Null Hypothesis: MOROCCO is a random walk

\begin{tabular}{ccccc}
\hline \hline \multicolumn{2}{c}{ Joint Tests } & Value & Df & Probability \\
\hline \hline \multicolumn{2}{c}{ Max $|z|$ (at period 2) } & 6.690107 & 262 & 0.0000 \\
Wald (Chi-Square) & 66.23451 & 15 & 0.0000 \\
\hline \multicolumn{2}{c}{ Individual Tests } & Std. Error & Z-Statistic & Probability \\
\hline Period & Var. Ratio & 0.061780 & -6.690107 & 0.0000 \\
3 & 0.586684 & 0.092096 & -5.857401 & 0.0000 \\
4 & 0.460554 & 0.115580 & -5.257400 & 0.0000 \\
5 & 0.392349 & 0.135354 & -4.859554 & 0.0000 \\
6 & 0.342242 & 0.152725 & -4.649485 & 0.0000 \\
7 & 0.289909 & 0.168384 & -4.285292 & 0.0000 \\
8 & 0.278423 & 0.182748 & -4.043501 & 0.0000 \\
9 & 0.261057 & 0.196088 & -3.839667 & 0.0010 \\
10 & 0.247086 & 0.208594 & -3.647772 & 0.0020 \\
11 & 0.239097 & 0.220403 & -3.447709 & 0.0020 \\
12 & 0.240115 & 0.231619 & -3.385741 & 0.0020 \\
13 & 0.215799 & 0.242322 & -3.264243 & 0.0020 \\
14 & 0.209002 & 0.252577 & -3.140408 & 0.0020 \\
15 & 0.206806 & 0.262435 & -3.100992 & 0.0020 \\
16 & 0.186192 & 0.271938 & -3.002220 & 0.0020 \\
\hline \hline
\end{tabular}

Null Hypothesis: MSCI BOTSWANA is a random walk

\begin{tabular}{|c|c|c|c|c|}
\hline \multicolumn{2}{|c|}{ Joint Tests } & Value & Df & Probability \\
\hline \multicolumn{2}{|c|}{$\operatorname{Max}|z|($ at period 2) } & 7.520763 & 262 & 0.0000 \\
\hline \multicolumn{2}{|c|}{ Wald (Chi-Square) } & 69.48825 & 15 & 0.0000 \\
\hline \multicolumn{5}{|c|}{ Individual Tests } \\
\hline Period & Var. Ratio & Std. Error & z-Statistic & Probability \\
\hline 2 & 0.535366 & 0.061780 & -7.520763 & 0.0000 \\
\hline 3 & 0.382044 & 0.092096 & -6.709874 & 0.0000 \\
\hline 4 & 0.314353 & 0.115580 & -5.932220 & 0.0000 \\
\hline 5 & 0.232792 & 0.135354 & -5.668172 & 0.0000 \\
\hline 6 & 0.217761 & 0.152725 & -5.121885 & 0.0000 \\
\hline 7 & 0.196126 & 0.168384 & -4.774039 & 0.0000 \\
\hline 8 & 0.167817 & 0.182748 & -4.553709 & 0.0000 \\
\hline 9 & 0.167447 & 0.196088 & -4.245806 & 0.0000 \\
\hline
\end{tabular}




$\begin{array}{lllll}10 & 0.155706 & 0.208594 & -4.047548 & 0.0000 \\ 11 & 0.152728 & 0.220403 & -3.844198 & 0.0000 \\ 12 & 0.142877 & 0.231619 & -3.700582 & 0.0000 \\ 13 & 0.139674 & 0.242322 & -3.550342 & 0.0000 \\ 14 & 0.137687 & 0.252577 & -3.414063 & 0.0010 \\ 15 & 0.132647 & 0.262435 & -3.305025 & 0.0010 \\ 16 & 0.135084 & 0.271938 & -3.180562 & 0.0020\end{array}$

Null Hypothesis: MSCI KENYA is a random walk

\begin{tabular}{ccccc}
\hline \hline \multicolumn{2}{c}{ Joint Tests } & Value & Df & Probability \\
\hline \hline \multicolumn{2}{c}{ Max |z| (at period 3) } & 5.277858 & 262 & 0.0000 \\
Wald (Chi-Square) & 39.32152 & 15 & 0.0020 \\
\hline \multicolumn{2}{c}{ Individual Tests } & & & \\
Period & Var. Ratio & Std. Error & z-Statistic & Probability \\
\hline 2 & 0.735058 & 0.061780 & -4.288466 & 0.0000 \\
3 & 0.513928 & 0.092096 & -5.277858 & 0.0000 \\
4 & 0.403069 & 0.115580 & -5.164648 & 0.0000 \\
5 & 0.342786 & 0.135354 & -4.855532 & 0.0000 \\
6 & 0.319032 & 0.152725 & -4.458795 & 0.0000 \\
7 & 0.282944 & 0.168384 & -4.258443 & 0.0000 \\
8 & 0.238923 & 0.182748 & -4.164619 & 0.0000 \\
9 & 0.195251 & 0.196088 & -4.104010 & 0.0000 \\
10 & 0.163245 & 0.208594 & -4.011405 & 0.0000 \\
11 & 0.165467 & 0.220403 & -3.786402 & 0.0000 \\
12 & 0.162855 & 0.231619 & -3.614325 & 0.0010 \\
13 & 0.156251 & 0.242322 & -3.481936 & 0.0020 \\
14 & 0.150508 & 0.252577 & -3.363303 & 0.0020 \\
15 & 0.143493 & 0.262435 & -3.263698 & 0.0020 \\
16 & 0.139327 & 0.271938 & -3.164959 & 0.0020 \\
\hline \hline
\end{tabular}

Null Hypothesis: MSCI NIGERIA is a random walk

\begin{tabular}{|c|c|c|c|c|}
\hline \multicolumn{2}{|c|}{ Joint Tests } & Value & Df & Probability \\
\hline \multicolumn{2}{|c|}{$\operatorname{Max}|z|($ at period 2) } & 6.071336 & 262 & 0.0000 \\
\hline \multicolumn{2}{|c|}{ Wald (Chi-Square) } & 46.99429 & 15 & 0.0000 \\
\hline \multicolumn{5}{|c|}{ Individual Tests } \\
\hline Period & Var. Ratio & Std. Error & z-Statistic & Probability \\
\hline 2 & 0.624912 & 0.061780 & -6.071336 & 0.0000 \\
\hline 3 & 0.500639 & 0.092096 & -5.422151 & 0.0000 \\
\hline 4 & 0.411376 & 0.115580 & -5.092779 & 0.0000 \\
\hline 5 & 0.327961 & 0.135354 & -4.965062 & 0.0000 \\
\hline 6 & 0.297397 & 0.152725 & -4.600450 & 0.0000 \\
\hline 7 & 0.270783 & 0.168384 & -4.330669 & 0.0000 \\
\hline 8 & 0.259779 & 0.182748 & -4.050492 & 0.0000 \\
\hline 9 & 0.250484 & 0.196088 & -3.822339 & 0.0010 \\
\hline 10 & 0.236718 & 0.208594 & -3.659174 & 0.0010 \\
\hline 11 & 0.214111 & 0.220403 & -3.565696 & 0.0010 \\
\hline 12 & 0.202486 & 0.231619 & -3.443222 & 0.0020 \\
\hline 13 & 0.184131 & 0.242322 & -3.366882 & 0.0030 \\
\hline 14 & 0.183598 & 0.252577 & -3.232295 & 0.0040 \\
\hline 15 & 0.177792 & 0.262435 & -3.133000 & 0.0050 \\
\hline 16 & 0.174375 & 0.271938 & -3.036078 & 0.0060 \\
\hline
\end{tabular}

Null Hypothesis: SOUTH AFRICA is a random walk

\begin{tabular}{|c|c|c|c|c|}
\hline \multicolumn{2}{|c|}{ Joint Tests } & Value & Df & Probability \\
\hline \multicolumn{2}{|c|}{ Max $|z|($ at period 2) } & 7.221207 & 262 & 0.0000 \\
\hline \multicolumn{2}{|c|}{ Wald (Chi-Square) } & 72.85562 & 15 & 0.0000 \\
\hline \multicolumn{5}{|c|}{ Individual Tests } \\
\hline Period & Var. Ratio & Std. Error & z-Statistic & Probability \\
\hline 2 & 0.553872 & 0.061780 & -7.221207 & 0.0000 \\
\hline
\end{tabular}




\begin{tabular}{ccccc}
3 & 0.357850 & 0.092096 & -6.972574 & 0.0000 \\
4 & 0.283339 & 0.115580 & -6.200557 & 0.0000 \\
5 & 0.242820 & 0.135354 & -5.594086 & 0.0000 \\
6 & 0.235615 & 0.152725 & -5.004983 & 0.0000 \\
7 & 0.195174 & 0.168384 & -4.779692 & 0.0000 \\
8 & 0.181556 & 0.182748 & -4.478529 & 0.0000 \\
9 & 0.174921 & 0.196088 & -4.207687 & 0.0000 \\
10 & 0.149669 & 0.208594 & -4.076489 & 0.0000 \\
11 & 0.139269 & 0.220403 & -3.905264 & 0.0000 \\
12 & 0.131730 & 0.231619 & -3.748706 & 0.0000 \\
13 & 0.132851 & 0.242322 & -3.578502 & 0.0000 \\
14 & 0.114623 & 0.252577 & -3.505380 & 0.0000 \\
15 & 0.114850 & 0.262435 & -3.372839 & 0.0000 \\
16 & 0.116130 & 0.271938 & -3.250261 & 0.0000 \\
\hline \hline
\end{tabular}

Source: Own elaboration

\section{CONCLUSION}

The general conclusion that we can retain, given the results obtained, through tests performed with econometric and mathematical models, that the indices of African markets do not follow the random walk hypothesis in this period of the global pandemic. The results suggest that the ratios of variances are lower than the unit, which implies that the yields are autocorrelated in time and, there is reversal to the mean. The authors show that the high sensitivity of prices to the arrival of new information will be due to the climate of pessimism and uncertainty experienced by investors during this period of global pandemic.

\section{REFERENCES}

Abakah, E. J.A. et al. (2018) 'Non-linear approach to Random Walk Test in selected African countries', International Journal of Managerial Finance. doi: 10.1108/IJMF-10-20170235 .

Aggarwal, D. (2018) 'Random walk model and asymmetric effect in Korean composite stock price index', Afro-Asian J. of Finance and Accounting. doi: 10.1504/aajfa.2018.10009906.

Alexandre, P., Dias, R. and Heliodoro, P. (2020) 'EUROPEAN FINANCIAL MARKET INTEGRATION: A CLOSER LOOK AT GOVERNMENT BONDS IN EUROZONE COUNTRIES', Balkans Journal of Emerging Trends in Social Sciences. doi: 10.31410/balkans.jetss.2020.3.1.78-86.

Alexandre, P., Heliodoro, P. and Dias, R. (2019) 'THE CONTAGION EFFECT IN EUROPE: A DCC GARH APPROACH', in 5th LIMEN Conference Proceedings (part of LIMEN conference collection). doi: 10.31410/limen.2019.73.

Breitung, J. (2000) 'The local power of some unit root tests for panel data', Advances in Econometrics. doi: 10.1016/S0731-9053(00)15006-6.

Clemente, J., Montañés, A. and Reyes, M. (1998) 'Testing for a unit root in variables with a double change in the mean', Economics Letters, 59(2), pp. 175-182. doi: 10.1016/S01651765(98)00052-4.

Dias, R., Heliodoro, P., et al. (2020a) 'FINANCIAL MARKET INTEGRATION OF ASEAN5 WITH CHINA: AN ECONOPHYSICS APPROACH', in 4th EMAN Conference Proceedings (part of EMAN conference collection). doi: 10.31410/eman.2020.17.

Dias, R., Sparrow, P., et al. (2020) 'Financial Market Integration of ASEAN-5 with China', Littera Scripta. doi: 10.36708/littera_scripta2020/1/4.

Dias, R., Heliodoro, P., et al. (2020b) 'THE SHOCKS BETWEEN OIL MARKET TO THE BRIC STOCK MARKETS: A GENERALIZED VAR APPROACH', in 4th EMAN Conference Proceedings (part of EMAN conference collection). 
Dias, R., Alexandre, P. and Heliodoro, P. (2020) 'Contagion in the LAC Financial Markets: The Impact of Stock Crises of 2008 and 2010', Littera Scripta. doi: 10.36708/littera_scripta2020/1/3.

Dias, R., Heliodoro, P. and Alexandre, P. (2019) 'RISK TRANSMISSION AMONG STOCK MARKETS IN LAC REGION: FINANCIAL CRISES IMPACT', in 5th LIMEN Selected Papers (part of LIMEN conference collection). doi: 10.31410/limen.s.p.2019.91.

Dias, R., Heliodoro, P. and Alexandre, P. (2020) 'Efficiency of Asean-5 Markets: An Detrended Fluctuation Analysis', Mednarodno inovativno poslovanje = Journal of Innovative Business and Management. doi: 10.32015/jibm.2020.12.2.13-19.

Dias, R., da Silva, J. V. and Dionísio, A. (2019) 'Financial markets of the LAC region: Does the crisis influence the financial integration?', International Review of Financial Analysis. Elsevier, 63(January), pp. 160-173. doi: 10.1016/j.irfa.2019.02.008.

Hawaldar, I. T., Rohith, B. and Pinto, P. (2020) 'Testing of Weak Form of Efficient Market Hypothesis: Evidence from the Bahrain Bourse', SSRN Electronic Journal. doi: 10.2139/ssrn.3504485.

He, Q. et al. (2020) 'The impact of COVID-19 on stock markets', Economic and Political Studies. doi: 10.1080/20954816.2020.1757570.

Heliodoro, P. et al. (2020) 'INTEGRATION IN BRIC STOCK MARKETS: AN EMPIRICAL ANALYSIS', in 4th EMAN Selected Papers (part of EMAN conference collection). doi: 10.31410/eman.s.p.2020.33.

Heliodoro, P., Dias, R. and Alexandre, P. (2020) 'FINANCIAL CONTAGION BETWEEN THE US AND EMERGING MARKETS: COVID-19 PANDEMIC CASE', in 4th EMAN Selected Papers (part of EMAN conference collection). doi: 10.31410/eman.s.p.2020.1.

Jain, E. (2020) 'Empirically testing weak form efficiency of Indian stock market: Pre and post demonetization', International Journal of Scientific and Technology Research.

Karasiński, J. (2020) 'The Changing Efficiency of the European Stock Markets', Annales Universitatis Mariae Curie-Sklodowska, sectio $H-$ Oeconomia. doi: 10.17951/h.2020.54.1.41-51.

Kelikume, I. (2016) 'New evidence from the efficient market hypothesis for the Nigerian stock index using the wavelet unit root test approach', The Journal of Developing Areas. doi: 10.1353/jda.2016.0041.

Lawal, A. I. et al. (2017) 'Examining the Nigerian stock market efficiency: Empirical evidence from wavelet unit root test approach', Journal of Applied Economic Sciences.

Lawal, A. I., Somoye, R. O. and Babajide, A. A. (2017) 'Are African stock markets efficient? Evidence from wavelet unit root test for random walk', Economics Bulletin.

Levin, A., Lin, C. F. and Chu, C. S. J. (2002) 'Unit root tests in panel data: Asymptotic and finite-sample properties', Journal of Econometrics. doi: 10.1016/S0304-4076(01)000987.

Lo, A. W. and MacKinlay, A.C. (1988) 'Stock Market Prices Do Not Follow Random Walks: Evidence from a Simple Specification Test', Review of Financial Studies. doi: 10.1093/rfs/1.1.41.

Obayagbona, J. and Igbinosa, S. O. (2015) 'Test of Random Walk Hypothesis in the Nigerian Stock Market', Current Research Journal of Social Sciences. doi: 10.19026/crjss.7.5220.

Rosenthal, L. (1983) 'An empirical test of the efficiency of the ADR market', Journal of Banking \& Finance. North-Holland, 7(1), pp. 17-29. doi: 10.1016/0378-4266(83)90053-5.

Sadat, A. R. and Hasan, M. E. (2019) 'Testing Weak Form of Market Efficiency of DSE Based on Random Walk Hypothesis Model: A Parametric Test Approach', International Journal of Accounting and Financial Reporting. doi: 10.5296/ijafr.v9i1.14454.

Sansa, N. A. (2020) 'The Impact of the COVID-19 on the Financial Markets: Evidence from China and USA', SSRN Electronic Journal. doi: 10.2139/ssrn.3567901. 
Simons, D. and Laryea, S. (2006) 'Testing the Efficiency of Selected African Stock Markets', Finance India. doi: 10.1.467.7105.

Smith, G., Jefferis, K. and Ryoo, H. J. (2002) 'African stock markets: Multiple variance ratio tests of random walks', Applied Financial Economics. doi: 10.1080/09603100010009957.

Tweneboah, G., Owusu, P. and Oseifuah, E. K. (2019) 'Integration of major African stock markets: Evidence from multi-scale wavelets correlation', Academy of Accounting and Financial Studies Journal. 